\title{
Effect of Streptomyces xantholiticus on Rice Blast Disease Reduction and Enzyme Activity
}

\author{
Hayman K. Awla* \\ Department of Plant Protection, Khabat Technical Institute, Erbil Polytechnic University, Erbil, Kurdistan Region, Iraq
}

\author{
${ }^{*}$ Corresponding author: \\ Hayman K. Awla, \\ Department of Plant \\ Protection, Khabat \\ Technical Institute, Erbil \\ Polytechnic University, Erbil, \\ Kurdistan Region, Iraq. \\ E-mail: hayman.awla@epu. \\ edu.iq
}

Received: 20 August 2020

Accepted: 25 November 2020

Published: 30 June 2021

DOI

10.25156/pti.v11n1y2021.pp112-117

\section{A B S T R A C T}

The rice blast infection triggered by Pyricularia oryzae Cav. is a grave issue restraining rice yields globally. Biological regulation has been seen as an encouraging option to such chemical fungicides. The biological control proficiency of 24 isolates of Streptomyces against $P$. oryzae (KT693184.1) has been examined. Analysis of defense enzymes such as polyphenol, peroxidase (PO), and total protein and phenol content was performed. The Streptomyces isolate that was determined to have maximum effectiveness was determined to be Streptomyces xantholiticus. The sequence was sent to the NCBI vide accession number MW029942. The S. xantholiticus isolate inhibited $P$. oryzae $92 \%$ using dual culture tests. The greenhouse experiments showed that the disease gravity in rice plants with $S$. xantholiticus isolate was considerably lower compared to plants sans the treatment. The $S$. xantholiticus isolate was analyzed for its effects concerning the activity of polyphenol and Po enzymes as well as the total protein content present in rice leaves under greenhouse conditions in both presence and absence of $P$. oryzae. It was found that rice species treated with the $S$. xantholiticus isolate had enhanced resistance to the rice blast pathogen along with increasing activity levels of the polyphenol and PO enzymes. There was a direct impact on pathogen growth along with the defense response triggered in the plants as a result of the treatment.

Keywords: Pyricularia oryzae; Peroxidase enzyme; Polyphenol oxidase; Plant growth; Biological control

\section{INTRODUCTION}

Rice is the principal food source for over three billion people across the globe. However, rice is susceptible to infections, the most damaging being rice blast, which is triggered by the fungus Magnaporthe oryzae (anamorph Pyricularia oryzae). This fungus attacks rice plants at all phases of development, leading to yearly losses of around 10-30\% in different rice producing areas (Law et al., 2017 and Couch et al., 2005).

The efforts to reduce the usage of fungicides make it essential to formulate cost-effective and effectual approaches to attain products from endogenous microorganisms under biocontrol application (Adnan et al., 2019). The biocontrol factors lead to the development of induced systemic resistance (ISR), enhancement of the mechanical and physical strength of the cell wall. Furthermore, the host undergoes biochemical and physiological changes, thereby causing the production of compounds that act as a defense against the pathogens.

Streptomyces species have been observed to be biocontrol agents useful against many plant pathogens (Prabavathy et al., 2006; Karthikeyan and Gnanamanickam, 2008) and have displayed the potential to create bioactive compounds, as well as decrease or deter mycelia growth of numerous fungi (Bressan and Figueiredo, 2008). The Streptomyces strain UPMRS4 was stated as a possible biocontrol agent for rice blast infection (Awla et al., 2016; Awla et al., 2017; Awla and Rashid, 2020). Furthermore, a higher activity of PO and polyphenol oxidase (PPO) in reaction to the infection by the pathogen is said to play a dynamic part in disease resistance in specific plant hosts. This is the pathogen interaction after the infection (Vidhyasekaran, 2004). According to Pradeep and Jambhale (2002), oxidative enzymes and phenolic compounds are said to be a vital biochemical factor for the aptitude of the plant to battle diseases. These bioactive compounds exhibit crucial uses in different domains. For instance, around $75 \%$ of commercially beneficial antibiotics were obtained from the genus Streptomyces and they are therefore the main antibiotic producing organisms manipulated by the pharmaceutical sector (Kashif et al., 2016). Streptomyces strains too have significant uses in the agricultural domain by means of their biological control ability against phytopathogens, mainly phytopathogenic fungi (González-Franco and RoblesHernandez, 2009). Chung et al., (2005) approved the 
ability of Streptomyces xantholiticus against Rhizoctonia solani to control of damping-off of Chinese cabbage (Brassica chinensis). Thus, the current work assesses the efficacy of $S$. xantholiticus to prompt systemic resistance against M. oryzae when contaminating rice plants.

\section{MATERIALS AND METHODS}

\section{Sample Collection and Isolation}

Samples of soil were gathered from rice irrigated fields of the Harir/Erbil rice growing region. Samples were picked from different depths from the surface and close to the root (Shahidi et al., 2005). The gathered samples were carried to the laboratory polymerase chain reaction for processing. Five spatulas from every soil sample were subject to air-drying at room temperature for 7-10 days (Shahidi et al., 2005). The Streptomyces were isolated using several dilutions using Streptomyces Isolation-agar (Difco ${ }^{\mathrm{TM}}$ ) medium along with cycloheximide $(100 \mu \mathrm{g} / \mathrm{mL})$ using $9 \mathrm{~cm}$ long Petri dishes. The incubation temperature was $28 \pm 2^{\circ} \mathrm{C}$, and the samples were monitored for 5 days. Then, the untreated culture was retained in Potato Dextrose Agar slants at $4^{\circ} \mathrm{C}$ for future use (Rahman et al., 2011).

\section{Antagonistic Activity}

The evaluation of the antagonistic activity against $P$. oryzae (Accession no. KT693184.1) was performed in vitro using 24 Streptomyces isolates (Dean et al., 2005). The streak technique was used in triplicate (Ramesh et al., 2009), and the incubation temperature of the plates was set to $28 \pm 2^{\circ} \mathrm{C}$. The antagonistic impact of the tested fungus was assessed through the formula given below:

$$
\mathrm{I}=\left[\frac{\mathrm{C}-\mathrm{T}}{\mathrm{C}}\right] 100
$$

where:

$\mathrm{I}=\%$ of inhibition in the mycelia growth.

$\mathrm{C}=$ the growth of pathogens in the control plates.

$\mathrm{T}=$ the growth of pathogens in the dual culture plates.

\section{Streptomyces Identification}

The optimal Streptomyces isolate was selected as per the antagonistic activity. The cetyltrimethylammonium bromide technique (Awla et al., 2017) was used for genomic DNA removal from the Streptomyces isolate. For the identified Streptomyces isolate, the $16 \mathrm{~S} \mathrm{rDNA}$ sequences were aligned as per the sequences of the indicative bacteria from the Streptomyces submitted to the GenBank (NCBI).

\section{In vivo Activity}

The soil was taken from Erbil Governorate ( $\mathrm{pH}$ 5.5-6). Its constitution was sand, clay, and organic matter in 1:1:1 v/v concentration. The soil sample was air-dried and sent through a sieve $(0.5 \mathrm{~mm})$; the sample was subsequently sterilized for $60 \mathrm{~min}$ at $121^{\circ} \mathrm{C}$ using an autoclave after which, it was left off to cool for $24 \mathrm{~h}$ before any subsequent test. The surface sterilization of the rice seeds was conducted by soaking them in $95 \%$ ethanol solution for $10 \mathrm{~s}$; subsequently, the seeds were treated with $3 \%$ sodium hypochlorite solution for $60 \mathrm{~s}$. Finally, the seeds were washed using sterile distilled water for a total of 6 times.

After surface sterilization, the rice seeds were planted directly into clean plastic seedling growth pots; the planting density was five seeds per pot. Tap water was used to water the plants every day. A completely randomized design comprising four replications was used to complete the experiment.

A conidial suspension comprising $S$. xantholiticus having a concentration of $10^{9} \mathrm{cfu} / \mathrm{ml}$ was diluted using $5 \mathrm{~L}$ of water, thereby resulting in a solution have a concentration of $2 \times 10^{5} \mathrm{cfu} / \mathrm{ml}$. $100 \mathrm{ml}$ of the diluted solution was used of $S$. xantholiticus for every pot (Mahato et al., 2018). After 1 day P. oryzae conidia suspension containing $3 \times 10^{5}$ conidia $/ \mathrm{ml}(15 \mathrm{ml} /$ pot) (Chen et al., 2001) was sprayed on the rice seedlings and after 5 days, lesion lengths developed on inoculated leaves.

\section{Total Protein Content Measurement}

The protein concentration was ascertained through the Bradford assay technique, explained by Arora and Wisniewsk (1994).

\section{Determination of Total Phenolic Content}

The overall phenolic content of the inoculated and un-inoculated rice leaves was ascertained through FolinCiocalteu assay (Noreen et al., 2017).

\section{Quantification of PPO Activity}

The mixture used for the reaction comprised $0.5 \mathrm{ml}$ of the enzyme extract was mixed with $2.3 \mathrm{ml}$ phosphate buffer of $0.1 \mathrm{M}$ concentration ( $\mathrm{pH}-6.1$ ). These solutions were mixed using a cuvette and adjusted so that the spectrophotometer reflected zero absorbance (Mahadevan and Sridhar, 1982). Subsequently, $0.2 \mathrm{ml}$ of catechol solution of $0.1 \mathrm{M}$ concentration was added to the mixture and mixed swiftly. Changes to absorbance, measured per minute, (ÄA/min) were used to determine enzyme activity; changes were observed at $400 \mathrm{~cm}$ just after $0.2 \mathrm{ml}$ of the $0.1 \mathrm{M}$ catechol solution was added. The catechol solution started the reaction.

\section{Quantification of PO Activity}

The activity of the PO enzyme was ascertained using the leaves of the un-inoculated rice plants, and those from 
inoculated plants (Sreedevi et al., 2011). $0.5 \mathrm{~g}$ of the fresh harvest was ground using a pre-cooled mortar filled with $20 \mathrm{ml}$ of the $0.1 \mathrm{M}$ concentration phosphate buffer ( $\mathrm{pH} 7.1)$ at ice-cold temperature; subsequently, the solution was subjected to $2000 \mathrm{RPM}$ centrifugation for $10 \mathrm{~min}$. The supernatant used for the assay comprised $25 \mathrm{ml}$ Pyrogallol reagent having $0.2 \mathrm{M}$ concentration was freshly prepared, and $0.1 \mathrm{ml}$ of this reagent was mixed with $1.4 \mathrm{ml}$ phosphate buffer (0.1 M, pH-7.1) and $1.0 \mathrm{ml}$ of enzyme extract using a cuvette tube. Immediately after mixing, the solution was adjusted so that it reflected zero absorbance on the spectrophotometer. Cuvette inversion was used to mix the $0.5 \mathrm{ml}, 0.01 \mathrm{M}$ hydrogen peroxide solution that was added to the initial solution. The change in absorbance per minute ( $\ddot{A} / \mathrm{min}$ ) at $430 \mathrm{~cm}$ was used to monitor enzyme activity.

\section{RESULTS AND DISCUSSION}

\section{Antagonistic Activity}

The results indicate that one isolate from a total of 24 produces the highest antagonism against $P$. oryzae, where the radial growth inhibition was $92 \%$. The isolate has been determined to be $S$. xantholiticus and has been sent to the NCBI (accession number: MW029942). Several studies have indicated that Streptomyces spp. is able to control P. oryzae for example, Streptomyces spp. (Rhee, 2003; Law et al., 2017; Awla et al., 2017; Bibb, 2005); Streptomyces sindeneusis (Zarandi et al., 2009), and Streptomyces globisporus (Li et al., 2011).

\section{Disease Suppression}

Plant growth and disease development witnessed significant impact as a result of the glasshouse experiment given the non-homogenous nature of the glasshouse. It took 3 days for the symptoms to appear as purple spots then changed to spindle-shaped lesions with gray center and reddish-brown border eventually surrounded by a yellow zone.

\section{Total protein Content}

A marked decrease was observed concerning the total soluble protein amount in the case of rice plants infected by $P$. oryzae; the measurements were taken after 5, 10, 15, and 20-day intervals, as showed in Figure 1. S. xantholiticus was observed to have higher effectiveness in increasing the total protein content for infected plants compared to the control samples. Observations indicated a significant rise in proteins for all the cases where the rice plants inoculated with the pathogen and S. xantholiticus. At the same time, the plants that received only the pathogen inoculation had the lowest amount of protein. The observed and significant decrease in rice tissue due to the infection could be attributed to specific activities triggered by a hypersensitive response (Chandra and Bhatt, 1998). Such defense reactions are triggered as a result of the build-up of PR proteins such as phenylalanine ammonialyase, phenolics, citinase, $\hat{a}-13$-glucanes, phytoalexins, and PO (Christopher et al., 2010).

\section{PO Enzyme Activity}

Figure 2 showed the activity specific to the PO enzyme. A significant increase in $\mathrm{PO}$ was observed for all samples compared to the control sample after increasing the period. All rice plants except those inoculated with $S$. xantholiticus and the control samples, $\mathrm{PO}$ activity witnessed a rise till the $10^{\text {th }}$ day; subsequently, the activity levels were either stable or reducing.

Several antioxidants such as PPO and PO may be responsible for oxygen metabolism happening in a diseased plant (Morkunas and Gmerek, 2007). The previous research indicates the higher activity of such enzymes at the hosttissue level as a consequence of the pathogenic infections (Abo-Elyousr and El-Hendawy, 2008, Christopher et al., 2010; Ojha and Chatterjee, 2012).

Figure 3 showed the total phenol level as a consequent of S. xantholiticus and the pathogen. The control specimens

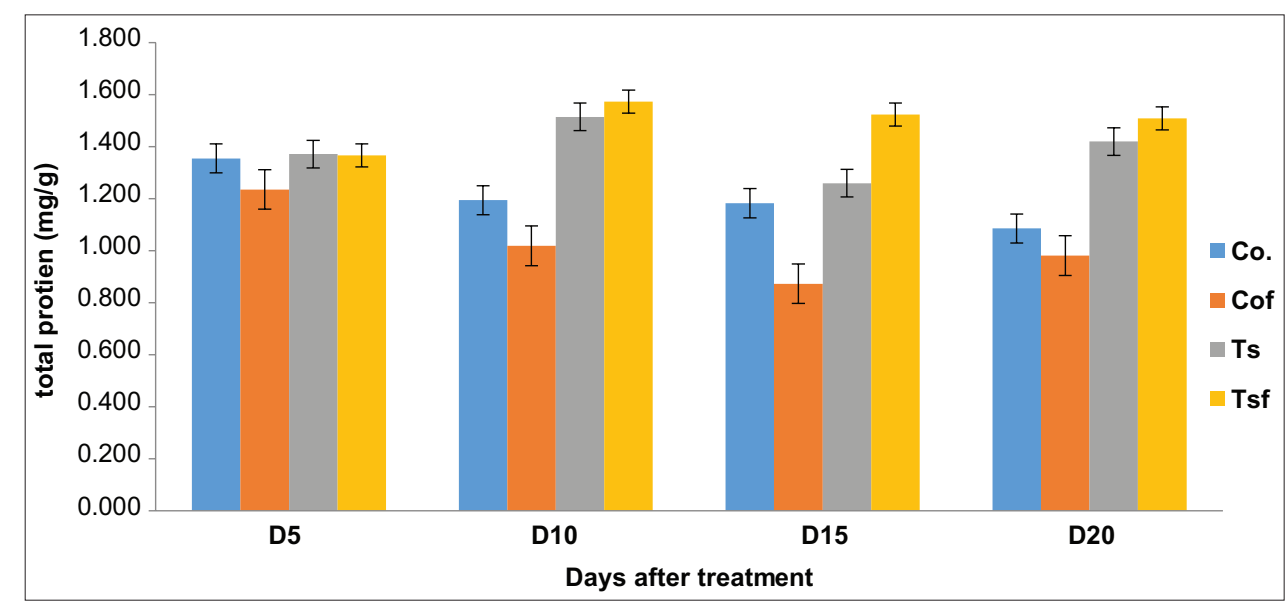

Figure 1: Effect of Streptomyces xantholiticus on the total protein content $(\mathrm{mg} / \mathrm{g})$ of the inoculated rice plants with $P$. oryzae. (Co.=Control, Cof $=$ Inoculated plant, Ts = Plant with Streptomyces, and Tsf = Inoculated plant with Streptomyces) 


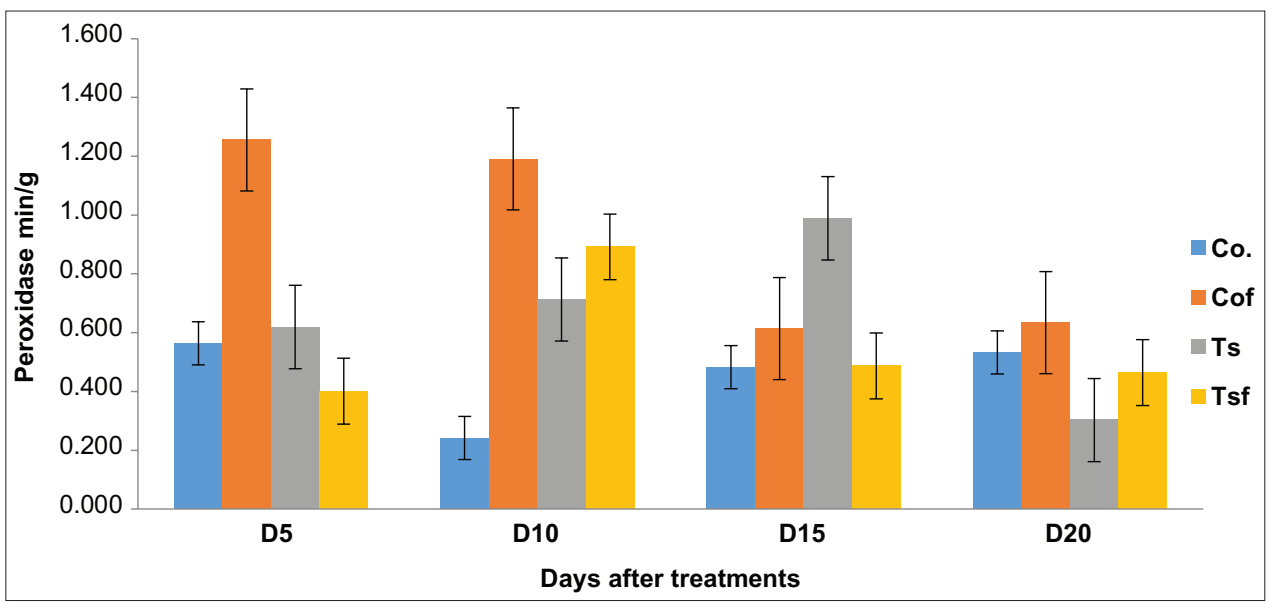

Figure 2: Effect of Streptomyces xantholiticus on the peroxidase activity of the inoculated rice plants with Pyricularia oryzae

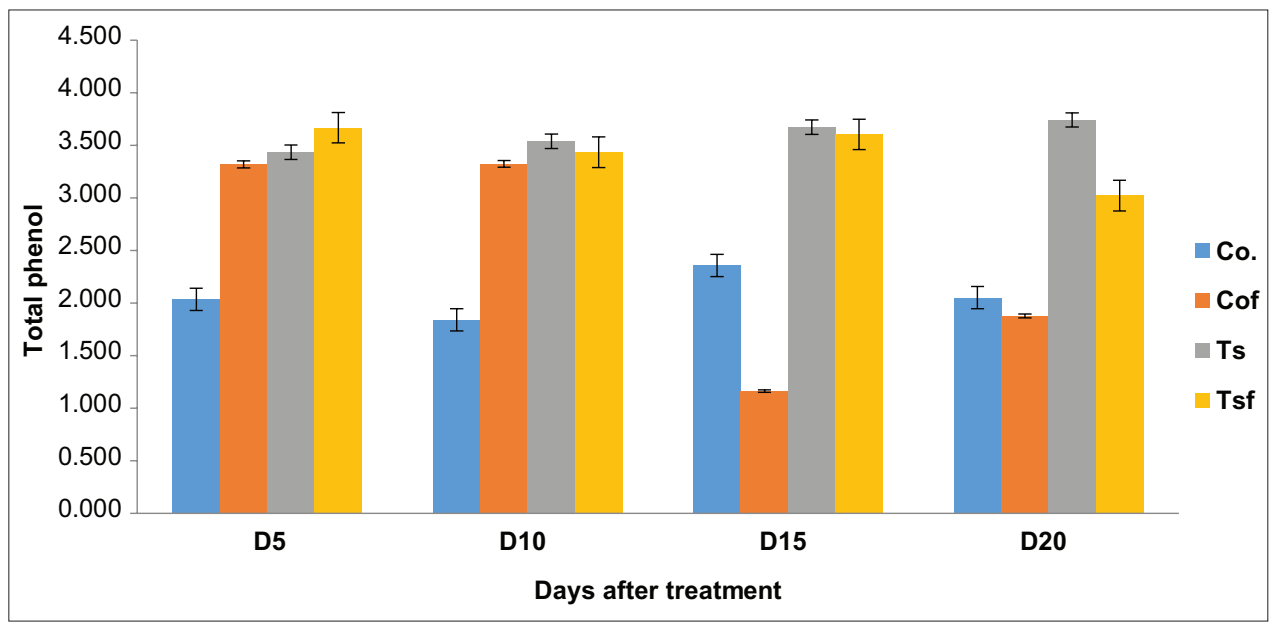

Figure 3: Effect of Streptomyces xantholiticus on the total phenol of the inoculated rice plants with Pyricularia oryzae

were found to have the lowest phenol levels at the $5^{\text {th }}$ and the $10^{\text {th }}$ days after beginning the treatment; a small increase in the phenol level is observed on the $15^{\text {th }}$ day. Samples inoculated with the pathogen, S. xantholiticus, and a combination of these two demonstrated an increase on the $5^{\text {th }}$ and $10^{\text {th }}$ days of the treatment. Concerning the plans inoculated with only the pathogen were found to have lesser phenol on the $15^{\text {th }}$ day, as opposed to an increase on the $20^{\text {th }}$ day. At the same time, the plants treated with S. xantholiticus are found to have the highest total phenol level, and they retain that level.

On the $5^{\text {th }}$ and the $10^{\text {th }}$ day of the experiment, the rice plants inoculated with $S$. xantholiticus were found to have higher polyphenol activity, which decreased slightly on the $15^{\text {th }}$ day and witnessed an increase on the $20^{\text {th }}$ day [Figure 4]. Control specimens and the plans inoculated only with the pathogen were found to have the lowest polyphenol level for the complete duration of the treatment. At the same time, specimens inoculated with the pathogen and then treated using $S$. xantholiticus were found to have a high increase in polyphenol levels on the $5^{\text {th }}$ day, which then decreased gradually during the remaining duration of the experiment.

Numerous studies suggest a rise in polyphenol and PO enzyme levels during the use of Streptomyces. One example is soil application and seed treatment using Streptomyces sp., which has a very pronounced effect on the polyphenol and PO activity levels in mung bean (Vigna radiata) (Adhilakshmi et al., 2014). Higher activity of the PO (POX) and PPO enzymes in the plants treated using Streptomyces indicates the development of biocontrol-ISR in the case of cucumber, unlike Phytophthora drechsleri (Sadeghi et al., 2017). The results indicate that treatments using Streptomyces bygroscopicus subsp. angustmyceticus NR8-2 led to an increase in the activity levels of PO, phenylalanine ammonia-lyase, and PPO enzymes present in oil palm (Sunpapao et al., 2018). Higher activity levels of PPO-1 and PPO- 2 of the treated samples compared to the control samples were observed for groundnut species treated using the three strains of Streptomyces sp. using a seed-and-soil 


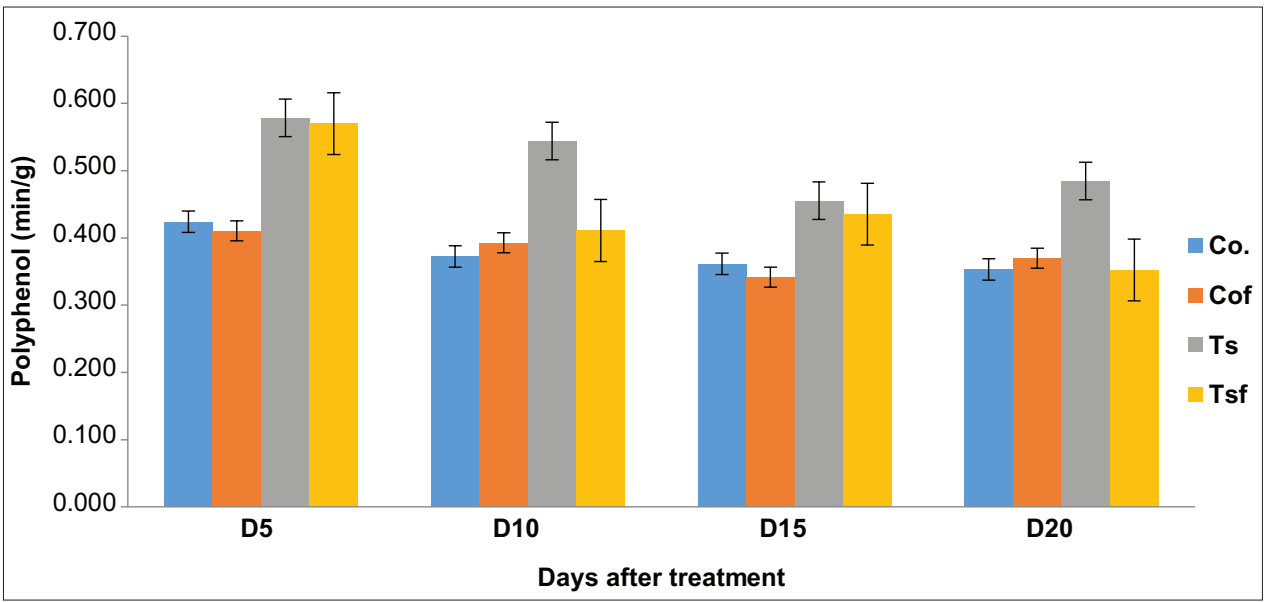

Figure 4: Effect of Streptomyces xantholiticus on the polyphenol activity of the inoculated rice plants with Pyricularia oryzae

combination, only seed, or control rotting of the stem as a consequence of Sclerotium rolfsii (Adhilakshmi and Velazhahan, 2013).

One study concerning Bacillus subtilis for controlling M. oryzae indicated higher PO and PPO activities. At the same time, the activity of superoxide dismutase was significantly higher for rice species sprayed with B. subtilis (Sha et al., 2016).

\section{CONCLUSION}

Treated rice plant with $S$. xantholiticus is observed to have an ability for inducing specific localized and systemic resistance in response to $P$. oryzae infection. The plant responds by effecting a change in $\mathrm{PO}$ activity, PPO activity, and the total levels of phenol and protein. Such mechanisms facilitate resistance build-up in rice species. The present study suggests that triggering a plant's natural defense systems using biocontrol substance is a useful technique for disease management in rice.

\section{REFERENCES}

Abo-Elyousr, K. A. and H. H. El-Hendawy. 2008. Integration of Pseudomonas fluorescens and acibenzolar-S-methyl to control bacterial spot disease of tomato. Crop Protect. 27(7): 1118-1124.

Adhilakshmi, M. and R. Velazhahan. 2013. Analysis of peroxidase and polyphenol oxidase isozyme profiles in groundnut plants treated with Streptomyces sp. Madras Agric. J. 100: 879-882.

Adhilakshmi, M., V. Paranidharan, D. Balachandar, K. Ganesamurthy and R. Velazhahan. 2014. Suppression of root rot of mung bean (Vigna radiata L.) by Streptomyces sp. is associated with induction of peroxidase and polyphenol oxidase. Arch. Phytopathol. Plant Protect. 47(5): 571-583.

Adnan, M., W. Islam, A. Shabbir, K. A. Khan, H. A. Ghramh, Z. Huang, H. Y. Chen and G. D. Lu. 2019. Plant defense against fungal pathogens by antagonistic fungi with Trichoderma in focus. Microb. Pathogen. 129: 7-18.

Arora, R. and M. E. Wisniewski. 1994. Cold acclimation in genetically related (sibling) deciduous and evergreen peach (Prunus persica (L.) Batsch) II. A 60-kilodalton bark protein in cold-acclimated tissues of peach is heat stable and related to the dehydrin family of proteins. Plant Physiol. 105(1): 95-101.

Awla, H. K. and T. S. Rashid. 2020. HPLC fractionation: A comparative analysis of anti-fungal compounds from different Streptomyces isolates inhibiting Colletotrichum acutatum. Biocatal. Agric. Biotechnol. 27: 101688.

Awla, H. K., J. Kadir, R. Othman, T. S. Rashid and M. Y. Wong. 2016. Bioactive compounds produced by Streptomyces sp. Isolate UPMRS4 and antifungal activity against Pyricularia ioryzae. Am. J. Plant Sci. 7(7): 1077-1085.

Awla, H. K., J. Kadir, R. Othman, T. S. Rashid, S. Hamid and M. Y. Wong 2017. Plant growth-promoting abilities and biocontrol efficacy of Streptomyces sp. UPMRS4 against Pyricularia oryzae. Biol. Control. 112: 55-63.

Bibb, M. J. 2005. Regulation of secondary metabolism in streptomycetes. Curr. Opin. Microbiol. 8(2): 208-215.

Bressan, W. and J. E. F. Figueiredo. 2008. Efficacy and doseresponse relationship in biocontrol of Fusarium disease in maize by Streptomyces spp. Eur. J. Plant Pathol. 120(3): 311-316.

Chandra, A. and R. K. Bhatt. 1998. Biochemical and physiological response to salicylic acid in relation to the systemic acquired resistance. Photosynthetica. 35(2): 255-258.

Chen, H. L., B. T. Chen, D. P. Zhang, Y. F. Xie and Q. Zhang. 2001. Pathotypes of Pyricularia grisea in rice fields of central and Southern China. Plant Dis. 85(8): 843-850.

Christopher, D. J., T. S. Raj, S. U. Rani and R. Udhayakumar. 2010. Role of defense enzymes activity in tomato as induced by Trichoderma virens against Fusarium wilt caused by Fusarium oxysporum f sp. Lycopersici. J. Biopest. 3(1): 158.

Chung, W. C., J. W. Huang and H. C. Huang. 2005. Formulation of a soil biofungicide for control of damping-off of Chinese cabbage (Brassica chinensis) caused by Rhizoctonia solani. Biol. Control. 32(2): 287-294.

Couch, B. C., I. Fudal, M. H. Lebrun, D. Tharreau, B. Valent, P. Van Kim, J. L. Nottéghem and L. M. Kohn. 2005. Origins of hostspecific populations of the blast pathogen Magnaporthe oryzae in crop domestication with subsequent expansion of pandemic clones on rice and weeds of rice. Genetics. 170(2): 613-630.

Dean, R. A., N. J. Talbot, D. J. Ebbole, M. L. Farman, T. K. 
Mitchell, M. J. Orbach, M. Thon, R. Kulkarni, J. R. Xu, H. Pan and N. D. Read. 2005. The genome sequence of the rice blast fungus Magnaporthe grisea. Nature. 434(7036): 980-986.

González-Franco, A. C. and L. Robles-Hernandez. 2009. Actinomycetes as biological control agents of phytopathogenic fungi. Tecnociencia Chihuahua. 3(2): 64-73.

Karthikeyan, V. and S. S. Gnanamanickam. 2008. Biological control of Setaria blast (Magnaporthe grisea) with Bacteria strains. Crop Protect. 27: 263-267.

Kashif, M. D., V. Kumar, V. N. Kalpana and V. D. Rajeswari. 2016. Phylogenetic diversity and biological activity of actinomycetes isolated from Gulf of Mannar, Tamil Nadu, India. Pharm. Lett. 8: 16-24.

Law, J. W. F., H. L. Ser, T. M. Khan, L. H. Chuah, P. Pusparajah, K. G. Chan, B. H. Goh and L. H. Lee. 2017. The potential of Streptomyces as biocontrol agents against the rice blast fungus, Magnaporthe oryzae (Pyricularia oryzae). Front. Microbiol. 8: 3.

Li, Q., Y. Jiang, P. Ning, L. Zheng, J. Huang, G. Li, D. Jiang and T. Hsiang. 2011. Suppression of Magnaporthe oryzae by culture filtrates of Streptomyces globisporus JK-1. Biol. Control. 58(2): 139-148.

Mahadevan, A. and R. Sridhar. 1982. Methods in Physiological Plant Pathology. Sivakami Publication, India. p316.

Mahato, S., S. Bhuju and J. Shrestha. 2018. Effect of Trichoderma viride as biofertilizer on growth and yield of wheat. Malays. J. Sustain. Agric. 2(2): 1-5.

Morkunas, I. and J. Gmerek. 2007. The possible involvement of peroxidase in defense of yellow lupine embryo axes against Fusarium oxysporum. J. Plant Physiol. 164(2): 185-194.

Noreen, H., N. Semmar, M. Farman and J. S. McCullagh. 2017. Measurement of total phenolic content and antioxidant activity of aerial parts of medicinal plant Coronopus didymus. Asian Pac. J. Trop. Med. 10(8): 792-801.

Ojha, S. and N. C. Chatterjee. 2012. Induction of resistance in tomato plants against Fusarium oxysporum f. sp. Lycopersici mediated through salicylic acid and Trichoderma harzianum. J. Plant Protect. Res. 52(2): 220-225.

Prabavathy, V. R., N. Mathivanan and K. Murugesan. 2006. Control of blast and sheath blight disease of rice using antifungal metabolites produced by Streptomyces sp. PM5. Biol. Control. 39: 313-319.

Pradeep, T. and N. D. Jambhale. 2002. Relationship between phenolics, polyphenol oxidase and peroxidases and resistance to powdery mildew in Zizhyphus. Indian Phytopathol. 55(2): 195-196.

Rahman, M., M. Z. Islam, M. Islam and A. UI Islam. 2011. Antibacterial activities of actinomycete isolates collected from soils of Rajshahi, Bangladesh. Biotechnol. Res. Int. 2011: 857925.

Ramesh, R., A. A. Joshi and M. P. Ghanekar. 2009. Pseudomonads: Major antagonistic endophytic bacteria to suppress bacterial wilt pathogen, Ralstonia solanacearum in the eggplant (Solanum melongena L.). World J. Microbiol. Biotechnol. 25(1): 47-55.

Rhee, K. H. 2003. Purification and identification of an antifungal agent from Streptomyces sp. KH-614 antagonistic to rice blast fungus, Pyricularia oryzae. J. Microbiol. Biotechnol. 13(6): 984-988.

Sadeghi, A., P. Koobaz, H. Azimi, E. Karimi and A. R. Akbari. 2017. Plant growth promotion and suppression of Phytophthora drechsleri damping-off in cucumber by cellulase-producing Streptomyces. BioControl. 62(6): 805-819.

Sha, Y., Q. Wang and Y. Li. 2016. Suppression of Magnaporthe oryzae and interaction between Bacillus subtilis and rice plants in the control of rice blast. SpringerPlus. 5(1): 1238.

Shahidi, B. G. H., P. Rashid Farrokhi, S. Aghighi, L. Shahidi Bonjar and A. Aghelizadeh. 2005. Antifungal characterization of actinomycetes isolated from Kerman, Iran and their future prospects in biological control strategies in greenhouse and field conditions. Plant Pathol. J. 4(1): 78-84.

Sreedevi, B., M. Charitha Devi and D. V. R. Saigopal. 2011. Isolation and screening of effective Trichoderma spp. against the root rot pathogen Macrophomina phaseolina. J. Agric. Technol. 7(3): 623-635.

Sunpapao, A., T. Chairin and S. I. Ito. 2018. The biocontrol by Streptomyces and Trichoderma of leaf spot disease caused by Curvularia oryzae in oil palm seedlings. Biol. Control. 123: 36-42.

Vidhyasekaran, P. 2004. Concise Encyclopedia of Plant Pathology. CRC Press, United States.

Zarandi, M. E., G. S. Bonjar, F. P. Dehkaei, S. A. Moosavi, P. R. Farokhi and S. Aghighi. 2009. Biological control of rice blast (Magnaporthe oryzae) by use of Streptomyces sindeneusis isolate 263 in greenhouse. Am. J. Appl. Sci. 6(1): 194-199. 